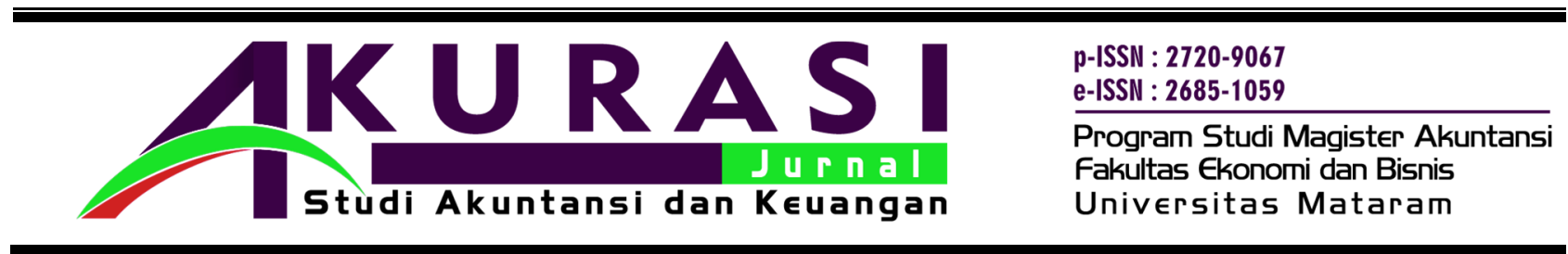

\title{
PENGARUH PENGUNGKAPAN SUSTAINABILITY REPORT TERHADAP KINERJA PERUSAHAAN PUBLIK DI INDONESIA
}

\author{
Winri Mulpiani ${ }^{1}$ \\ ${ }^{1}$ Jurusan Akuntansi FEB Universitas Mataram, email: winri.mulpiani@gmail.com
}

\section{INFORMASI ARTIKEL}

Article history:

Dikirim tanggal: 17 Agustus 2019

Revisi pertama tanggal: 4 September 2019

Diterima tanggal: 1 Desember 2019

Tersedia online tanggal 15 Desember 2019

\section{ABSTRAK}

Penelitian ini bertujuan untuk menguji pengaruh dimensi pengungkapan sustainability report yaitu dimensi ekonomi, dimensi lingkungan, dan dimensi sosial terhadap kinerja keuangan (ROA) dan kinerja pasar (Tobin's Q). Global Reporting Initiative (GRI) Standard digunakan sebagai pedoman pengungkapan sustainability report. Populasi penelitian ini adalah perusahaan yang tercatat di Bursa Efek Indonesia (BEI) selama periode 2015-2017. Sebanyak 26 perusahaan menjadi sampel penelitian dengan menggunakan teknik purpose sampling. Analisis data menggunakan regresi linier berganda. Hasil penelitian ini menunjukkan bahwa pengungkapan dimensi ekonomi, dimensi lingkungan berpengaruh signifikan terhadap kinerja keuangan tetapi tidak berpengaruh terhadap kinerja pasar, sedangkan dimensi sosial tidak berpengaruh terhadap kinerja keuangan dan kinerja pasar. Hasil penelitian ini memberikan implikasi bagi manajemen perusahaan untuk mempertimbangkan isu keberlanjutan dalam melakukan peningkatan kinerja keuangan perusahaan dan sebagai informasi bagi investor dalam menentukan keputusan investasi.

Kata-kata kunci: sustainability report, dimensi ekonomi, dimensi lingkungan, dimensi sosial, Return On Asset, Tobin's Q.

\begin{abstract}
This study aims to examine the effect of sustainability report disclosure dimensions, namely economic dimension, environmental dimension, and social dimensions on financial performance (ROA) and market performance (Tobin's Q). The Global Reporting Initiative (GRI) Standard index used as guideline for sustainability report disclosure. The population of this study are companies listed on the Indonesia Stock Exchange (IDX) during the 2015-2017 period. The sample of this study were 26 companies using purposive sampling technique. Data were analyzed using multiple linear regressions analysis. The results of this study indicate that the disclosure of economic dimensions and environmental dimensions significantly influence financial performance, but does not affect market performance. Meanwhile the social dimension does not affect neither financial performance nor market performance. The results of this study provide implications for corporate management to consider the issue of sustainability in improving corporate financial performance and as information for investors in determining investment decisions.
\end{abstract}

Keywords: Sustainability report, economic dimensions, environmental dimensions, social dimensions, Return On Asset, Tobin's $Q$.

C2019 FEB UNRAM. All rights reserved

\section{Pendahuluan}

Banyaknya kasus pencemaran lingkungan saat ini menjadi topik yang sangat menarik dan banyak mendapat perhatian dari berbagai pihak. Pencemaran lingkungan terjadi karena kelalaian perusahaan dalam mengelola usahanya yang tidak memantau dampak aktivitas operasional lingkungan. Seiring dengan banyaknya kasus lingkungan yang terjadi di Indonesia, perhatian pelaku bisnis terhadap pelaporan ekonomi, sosial dan lingkungan 
semakin meningkat dimana perusahaan mengembangkan konsep 3P yang diperkenalkan oleh Elkington (1988), yaitu People, Planet and Profit atau diskenal dengan konsep Triple Bottom-Line. Menurut Manisa dan Defung (2017), selain mengejar profit, perusahaan juga harus memperhatikan dan terlibat dalam pemenuhan kesejahteraan masyarakat (people) serta turut berkontribusi aktif dalam menjaga kelestarian lingkungan (planet). Konsep tersebut merupakan cerminan dari istilah yang dikenal berbagai perusahaan di dunia, yaitu Sustain Ability. Sustain Ability memiliki makna bagi perusahaan, yaitu kemampuan perusahaan untuk bertahan hidup selama mungkin atau disebut dengan long-life company.

Global Reporting Initiative (GRI) mendefinisikan sustainability report sebagai praktik dalam mengukur dan mengungkapkan aktivitas perusahaan, sebagai bentuk tanggung jawab kepada stakeholder internal dan eksternal mengenai kinerja organisasi dalam mewujudkan tujuan pembangunan berkelanjutan. Adapun tujuan pembangunan berkelanjutan adalah upaya memenuhi kebutuhan saat ini tanpa mengurangi kemampuan generasi yang akan datang dalam memenuhi kebutuhannya. Menurut Simbolon dan Memed (2016), sustainability report bagi perusahaan merupakan publikasi informasi yang mencerminkan kinerja organisasi dalam dimensi ekonomi, sosial, lingkungan yang dapat menjadi media bagi perusahaan untuk menginformasikan kinerja organisasi kepada seluruh pemangku kepentingan (stakeholders). Weber et al. (2008) menyatakan bahwa perusahaan yang mengungkapkan laporan keberlanjutan (sustainability report) ingin menunjukkan transparansi dan mendapatkan umpan balik pada kinerja perusahaan dalam menanggapi tuntutan informasi dari stakeholder. Bagi perusahaan, sustainability report merupakan alat ukur pencapaian target kerja dalam isu Triple Bottom Line. Bagi investor, sustainability report berfungsi sebagai alat kontrol atas capaian kinerja perusahaan sekaligus sebagai media pertimbangan investor dalam mengalokasikan sumber daya keuangannya. Sementara bagi pemangku kepentingan lainnya (media, pemerintah, konsumen, akademis dan lain-lain) sustainability report menjadi tolak ukur untuk menilai kesungguhan komitmen perusahaan terhadap pembangunan berkelanjutan (Putri, 2017).

Kecenderungan pengungkapan Sustainability Reporting di Indonesia mengalami peningkatan setiap tahunnya yang berawal pada tahun 2005 hanya satu perusahaan. Menurut National Center for Sustainability Reporting (NCSR), sampai akhir 2016 terdapat 120 perusahaan yang menerbitkan laporan keberlanjutan di Indonesia, baik perusahaan yang go public maupun perusahaan yang privat. Namun, jumlah tersebut masih jauh dibawah jumlah perusahaan yang tercatat pada bursa efek apalagi jika dibandingkan dengan jumlah seluruh perusahaan yang ada di Indonesia. Sustainability Report ini disusun dengan sebuah acuan atau dasar yaitu Global Reporting Initiative (GRI). GRI merupakan sebuah organisasi nonprofit yang mempromosikan keberlanjutan ekonomi. GRI menghasilkan standar yang umum digunakan perusahaan di dunia untuk pelaporan keberlanjutan seperti Enviromental Social Governance (ESG).

Penelitian ini bertujuan untuk memberikan bukti empiris tentang pengaruh pengungkapan dimensi keberlanjutan (ekonomi, sosial dan lingkungan) terhadap kinerja perusahaan, baik kinerja keuangan perusahaan maupun kinerja pasar. Dibandingkan penelitian sebelumnya, penelitian ini mempertimbangkan dimensi ekonomi, sosial dan lingkungan sebagai pembentuk laporan keberlanjutan perusahaan. Hasil penelitian ini memberikan kontribusi bahwa perusahaan bukanlah suatu entitas yang hanya beroperasi 
untuk kepentingannya sendiri, namun harus memberikan manfaat bagi stakeholder-nya seperti pemegang saham, kreditor, konsumen, supplier, pemerintah, masyarakat, analis, dan pihak lain. Adopsi isu keberlanjutan dalam kebijakan perusahaan merupakan cara untuk mendapatkan legitimasi beroperasi dan memenuhi harapan dari stakeholder. Bagi investor hasil penelitian ini memberikan informasi dalam mempertimbangkan aspek keberlanjutan dalam keputusan investasi serta fungsi kontrol sosial bagi masyarakat.

\section{Kerangka Teoritis Dan Pengembangan Hipotesis}

Istilah stakeholder pertama kali dikemukakan oleh Stanford Research Institute (SRI) pada tahun 1963 (Freeman, 1984). Stakeholder adalah kelompok maupun individu yang dapat mempengaruhi atau dipengaruhi oleh suatu proses pencapaian tujuan suatu organisasi. Pada dasarnya, teori stakeholder adalah sebuah teori yang menggambarkan kepada pihak mana saja sebuah organisasi atau perusahaan bertanggung jawab (Freeman, 1984). Inti dari pemikiran stakeholder theory mengarah pada keberadaan suatu organisasi sangat dipengaruhi oleh dukungan kelompok-kelompok yang memiliki hubungan dengan organisasi tersebut (Sejati dan Andri, 2015). Salah satu strategi perusahaan untuk menjaga hubungan dengan para stakeholder adalah dengan mengungkapkan sustainability report yang menginformasikan perihal kinerja ekonomi, sosial dan lingkungan (Karyawati dkk., 2017).

Berkaitan dengan keberlanjutan perusahaan, Teori Legitimasi dilandasi pada kontrak sosial yang terjadi antara perusahaan dengan masyarakat dimana perusahaan beroperasi dan menggunakan sumber ekonomi (Ghozali dan Chairiri, 2014: 442). Legitimasi dianggap menyamakan persepsi atau asumsi bahwa tindakan yang dilakukan oleh suatu entitas merupakan tindakan yang diinginkan, pantas atau sesuai dengan sistem norma, nilai, kepercayaan dan definisi yang dikembangkan secara sosial (Suchman, 1995 dalam Pratiwi dan Chariri, 2015). Teori Legitimasi mendorong perusahaan untuk meyakinkan bahwa aktivitas dan kinerjanya dapat diterima oleh masyarakat. Laporan aktivitas tanggungjawab sosial dan lingkungan perusahaan yang dituangkan dalam sustainability report dapat digunakan untuk membuktikan bahwa perusahaan telah menjalankan tanggung jawab sosial dan lingkungan sesuai dengan norma yang berlaku. Hal ini sebagai upaya agar keberadaan organisasi dapat diterima oleh masyarakat (Simbolon dan Memed, 2016).

Sustainability report merupakan sebuah laporan yang tidak hanya berisi tentang informasi kinerja keuangan suatu perusahaan tetapi juga informasi nonkeuangan yang terdiri dari informasi aktivitas sosial dan lingkungan perusahaan yang memungkinkan perusahaan tersebut dapat bertumbuh secara berkesinambungan (Elkington, 1997). Istilah sustainability report atau laporan keberlanjutan menurut Global Reporting Initiative (GRI) yaitu sebuah laporan yang diterbitkan oleh perusahaan atau organisasi yang berhubungan dengan dampak ekonomi, lingkungan serta sosial sebagai dampak dari aktivitas operasi perusahaan seharihari. Laporan keberlanjutan menyajikan nilai- nilai dan model tata kelola perusahaan atau organisasi, serta hubungan antara strategi dan komitmen perusahaan tersebut terhadap ekonomi global yang berkelanjutan (Maskat, 2018).

Kinerja perusahaan adalah suatu tampilan keadaan secara utuh atas perusahaan selama periode waktu tertentu yang merupakan hasil atau prestasi yang dipengaruhi oleh kegiatan operasional perusahaan dalam memanfaatkan sumber daya yang dimiliki. Dalam 
menentukan pengambilan keputusan, stakeholders memerlukan informasi terkait dengan kinerja perusahaan, dengan mengetahui kinerja perusahaan, stakeholders dapat mengukur tingkat efisiensi dan efektifitas perusahaan tersebut. Kinerja keuangan merupakan gambaran mengenai kondisi dan keadaan dari suatu perusahaan yang dianalisis dengan alat-alat analisis keuangan sehingga dapat diketahui baik buruknya kondisi keuangan dan prestasi keuangan sebuah perusahaan dalam waktu tertentu (Wibowo dan Faradiza, 2014 dalam Wijayanti, 2016). Pengukuran kinerja keuangan dapat dilakukan dengan penilaian analisis rasio keuangan. Analisis rasio keuangan merupakan dasar untuk menilai dan menganalisis prestasi operasi perusahaan atau kinerja perusahaan (Soelistyoningrum, 2011). Dalam penelitian ini rasio kinerja keuangan yang digunakan adalah rasio profitabilitas, yang mencerminkan kemampuan perusahaan menghasilkan laba. Kinerja pasar merupakan salah satu indikator yang digunakan oleh pihak internal maupun pihak eksternal dari perusahaan untuk bisa mengukur seberapa besar, maju, dan berkembangnya suatu perusahaan (Putri, 2017). Kinerja pasar lebih berfokus pada bagaimana investor melihat nilai perusahaan yang biasanya tercerminkan melalui harga saham atau deviden yang dibagikan (Maria, 2016).

Menurut Cahyandito (2010) dalam Putri (2017), pelaporan dimensi ekonomi dalam sustainability report akan meningkatkan transparansi perusahaan yang berdampak pada peningkatan kepercayaan investor dan kinerja keuangan. Pengungkapan sustainability report berdampak positif terhadap kinerja keuangan dikarenakan informasi yang diungkapkan dalam laporan dimensi ekonomi dapat meyakinkan potensi sumber daya modal yang kompetitif dengan tingkat risiko rendah pada stakeholder dan hal ini akan berpengaruh terhadap peningkatan laba, dengan meningkatnya laba maka kinerja keuangan juga akan meningkat. Berdasarkan uraian tersebut dapat dirumuskan hipotesis sebagai berikut: $\mathrm{H}_{1}$ : Pengungkapan dimensi ekonomi berpengaruh positif terhadap kinerja keuangan.

Pengungkapan dimensi lingkungan dimaksudkan untuk memberikan informasi yang relevan dan akurat mengenai dimensi lingkungan perusahaan kepada stakeholder. Laporan dimensi lingkungan digunakan oleh stakeholder untuk mengevaluasi dampak yang diakibatkan oleh operasi bisnis perusahaan terhadap lingkungan (Sejati dan Andri, 2015). Berdasarkan Teori Legitimasi, perusahaan perlu menunjukkan eksistensi dan keikutsertaan dalam penanganan masalah lingkungan sebagai bentuk tanggungjawab perusahaan secara moral terhadap lingkungan dimana perusahaan tersebut berada (Simbolon dan Memed 2016). Dengan adanya tanggung jawab tersebut, akan meningkatkan citra perusahaan. Dengan demikian pengungkapan sustainability report yang dilakukan perusahaan diharapkan dapat memberikan bukti nyata bahwa proses produksi yang dilakukan perusahaan juga memperhatikan isu sosial dan lingkungan, sehingga dapat meningkatkan kepercayaan stakeholder yang akan berdampak pada peningkatan investasi sehingga akan meningkatkan laba perusahaan (Karyawati dkk., 2017). Berdasarkan uraian tersebut dapat dirumuskan hipotesis sebagai berikut:

$\mathrm{H}_{2}$ : Pengungkapan dimensi lingkungan berpengaruh positif terhadap kinerja keuangan.

Dimensi sosial dalam sustainability report menyangkut dampak organisasi terhadap masyarakat dimana perusahaan beroperasi, dan menjelaskan risiko dari interaksi dengan 
institusi sosial lainnya (Wijayanti, 2016). Menurut Sejati dan Andri (2015) pengungkapan dimensi sosial digunakan untuk menarik minat stakeholder bekerja sama dengan perusahaan. Di satu sisi stakeholder membutuhkan kesejahteraan dan satu sisi lainnya perusahaan membutuhkan sumber daya manusia yang handal, kompetitif, kreatif dan efektif dalam mengelola aset perusahaan. Melalui peran perusahaan terhadap aspek sosial kemasyarakatan maka perusahaan mendapatkan legitimasi dan dukungan masyarakat. Ketika eksistensi perusahaan mendapat dukungan sosial baik dari masyarakat mapuan konsumen, maka kegiatan operasional perusahaan berjalan lancar sehingga dapat mendukung kemampuan perusahaan dalam memperoleh pendapatan. Dengan demikian dapat berkontribusi terhadap pencapaian kinerja keuangan perusahaan. Berdasarkan uraian tersebut dapat dirumuskan hipotesis sebagai berikut:

$\mathrm{H}_{3}$ : Pengungkapan dimensi sosial berpengaruh positif terhadap kinerja keuangan.

Pengungkapan dimensi ekonomi dalam sustainability report dipandang sebagai tindakan positif oleh perusahaan untuk menjaga kepercayaan, dan hubungan baik dengan investor dan kreditor yang akan berinvestasi di perusahaan. Kepercayaan investor dan kreditor dalam akuntabilitas perusahaan akan meningkatkan reputasi atau citra perusahaan. Hal ini berdampak positif dalam peningkatan kinerja pasar perusahaan untuk tahun-tahun berikutnya (Caesaria dan Basuki, 2017). Dengan capaian kinerja ekonomi yang baik, maka akan menguntungkan investor terkait investasi yang dilakukannya seperti keputusan investasi yang dilakukan dapat berupa permintaan terhadap pembelian saham perusahaan. Ketika permintaan saham tinggi maka akan mengakibatkan jumlah saham yang beredar di pasaran meningkat (Putri, 2017) sehingga dapat mempengaruhi kinerja pasar. Berdasarkan uraian tersebut dapat dirumuskan hipotesis sebagai berikut :

$\mathrm{H}_{4}$ : Pengungkapan dimensi ekonomi berpengaruh positif terhadap kinerja pasar.

Pengungkapan dimensi lingkungan meliputi dampak yang terkait dengan input (seperti energi dan air) dan output (seperti emisi, limbah, dan sampah). Penggunaan input dan output yang dihasilkan oleh perusahaan dapat memicu berbagai masalah lingkungan. Dengan adanya tanggungjawab perusahaan terhadap lingkungan maka akan meningkatkan image perusahaan yang akan berdampak pada permintaan saham, investor akan tertarik untuk berinvestasi di perusahaan tersebut karena perusahaan memiliki tanggungjawab terhadap lingkungan yang berarti perusahaan memiliki risiko lingkungan yang relatif rendah. Transparansi terhadap pengelolaan lingkungan tersebut akan meningkatkan kepercayaan investor sehingga permintaan saham perusahaan akan meningkat yang berarti nilai pasar perusahaan bertambah (Putri, 2017). Berdasarkan uraian tersebut dapat dirumuskan hipotesis sebagai berikut:

$\mathrm{H}_{5}$ : Pengungkapan dimensi lingkungan berpengaruh positif terhadap kinerja pasar.

Pengungkapan sustainability report kategori sosial akan berdampak pada persepsi stakeholder tentang perlakuan perusahaan terhadap sumber daya manusia di sekitarnya (Simbolon dan Memed, 2016). Dengan melaksanakan dan melaporkan tanggung jawab sosial terhadap para pemangku kepentingan tidak hanya dapat meningkatkan harga saham rata-rata perusahaan, tetapi juga dapat meningkatkan kesejahteraan dan loyalitas karyawan, 
menurunkan tingkat perputaran karyawan sehingga dapat berujung pada peningkatan produktivitas perusahaan (Ernst dan Young, 2013 dalam Tarigan dan Samuel, 2014). Dengan semakin terpenuhinya indeks dalam pengungkapan dimensi sosial, perusahaan memiliki nilai lebih di mata investor. Perusahaan dengan kinerja sosial yang baik akan diapresiasi positif oleh investor sehingga respon positif akan berdampak pada peningkatan harga saham. Berdasarkan uraian tersebut dapat dirumuskan hipotesis sebagai berikut : $\mathrm{H}_{6}$ : Pengungkapan dimensi sosial berpengaruh positif terhadap kinerja pasar.

\section{Metode Penelitian}

Jenis penelitian yang digunakan dalam penelitian ini adalah penelitian penjelasan (explanatory research). Penelitian penjelasan merupakan jenis penelitian dimana peneliti menjelaskan hubungan kausal antara variabel-variabel melalui pengujian hipotesis, yaitu menguji hipotesis-hipotesis berdasarkan teori yang telah dirumuskan sebelumnya kemudian data yang telah diperoleh dihitung melalui pendekatan kuantitatif (Sugiyono, 2018:37). Penelitian ini menguji hubungan kausalitas dimana terdapat variabel dependen yaitu kinerja perusahaan dan kinerja pasar, sedangkan variabel independen yaitu sustainability report. Populasi dalam penelitian ini adalah seluruh perusahaan yang terdaftar di Bursa Efek Indonesia periode 2015-2017. Pemilihan sampel pada penelitian ini menggunakan metode purposive sampling dengan sampel yang digunakan sejumlah 26 perusahaan. Dengan observasi selama 3 tahun yaitu 2015-2017 maka diperoleh jumlah observasi sebanyak 78 observasi.

Pada penelitian ini jenis data yang digunakan adalah data kuantitatif yang bersumber dari data sekunder berupa sustainability report dan laporan keuangan tahun 2015-2017 perusahaan publik di Indonesia yang dipublikasikan di website Bursa Efek Indonesia (BEI) yaitu www.idx.co.id maupun website masing-masing perusahaan. Kinerja perusahaan sebagai variabel dependen diukur menggunakan proksi Return on Asset (ROA) untuk kinerja keuangan dan Tobin's Q untuk kinerja pasar. Variabel independen dalam penelitian ini adalah dimensi ekonomi, dimensi lingkungan, dan dimensi sosial yang diukur dengan menggunakan Sustainability Report Disclosure Index. Pengukuran indeks pengungkapan untuk masing-masing dimensi keberlanjutan (ekonomi, lingkungan dan sosial) dilakukan dengan membagi nilai pengungkapan yang dilakukan oleh perusahaan untuk masing-masing dimensi keberlanjutan dibagi dengan total dimensi pengungkapan yang diharapkan. Jumlah indikator pengungkapan untuk dimensi ekonomi adalah 13 indikator, dimensi lingkungan 30 indikator dan dimensi sosial sebanyak 34 indikator.

Analisis regresi linier berganda digunakan dalam penelitian ini untuk mengetahui pengaruh masing-masing aspek dalam Sustainability Report (dimensi ekonomi, lingkungan dan sosial) terhadap kinerja perusahaan, yang diukur dengan kinerja keuangan dan kinerja pasar. Model persamaan matematis yang akan diuji dalam penelitian ini adalah sebagai berikut :

$\begin{array}{lll}\text { Kinerja Keuangan }(\mathrm{ROA}) & =\alpha+\beta 1 \mathrm{EcDI}+\beta 2 & \mathrm{EnDI}+\beta 3 \mathrm{SoDI}+\varepsilon \\ \text { Kinerja Pasar (Tobin's Q) } & =\alpha+\beta 1 \mathrm{EcDI}+\beta 2 & \mathrm{EnDI}+\beta 3 \mathrm{SoDI}+\varepsilon\end{array}$

Keterangan :

$\begin{array}{ll}\text { ROA } & =\text { Kinerja Keuangan } \\ \text { Tobin's Q } & =\text { Kinerja Pasar }\end{array}$ 


\begin{tabular}{|c|c|}
\hline$\alpha$ & $=$ Konstanta \\
\hline$\beta$ & $=$ Koefisien Regresi \\
\hline EcDI & $=$ Indeks dimensi ekonomi \\
\hline EnDI & $=$ Indeks dimensi lingkungan \\
\hline SoDI & $=$ Indeks dimensi sosial \\
\hline & $=$ Error \\
\hline
\end{tabular}

\section{Hasil dan Pembahasan}

Hasil analisis statistik deskriptif seluruh variabel menggambarkan nilai minimum, nilai maksimum, nilai rata-rata dan nilai standar deviasi. Variabel independen yang digunakan dalam penelitian ini adalah pengungkapan sustainability report yang diukur dengan pengungkapan dimensi ekonomi, dimensi lingkungan dan dimensi sosial. Sedangkan variabel dependen dalam penelitian ini adalah kinerja perusahaan, yang diukur dengan kinerja keuangan (ROA) dan kinerja pasar (Tobins Q). Hasil pengujian statistik deskriptif tersebut dapat dilihat pada tabel 1 berikut ini:

Tabel 1 Hasil Analisis Statistik Deskriptif

\begin{tabular}{cccccc}
\hline & N & Minimum & Maximum & Mean & $\begin{array}{c}\text { Std. } \\
\text { Deviation }\end{array}$ \\
\hline Ekonomi & 78 & .00 & 100.00 & 43.1949 & 23.49716 \\
Lingkungan & 78 & .00 & 100.00 & 30.0853 & 21.36110 \\
Sosial & 78 & 8.82 & 94.12 & 35.3319 & 19.93876 \\
ROA & 78 & -9.58 & 20.68 & 4.2235 & 4.99211 \\
Tobin's Q & 78 & .26 & 10.5 & 1.4714 & 1.5784 \\
Valid N (listwise) & 78 & & & & \\
\hline
\end{tabular}

Rata-rata nilai variabel dimensi ekonomi yang diukur dengan GRI Standard adalah 43,1949. Hal ini dapat diartikan bahwa rata-rata perusahaan yang dijadikan sampel mengungkapkan dimensi ekonomi dalam Sustainability Report sesuai indeks GRI Standar telah memenuhi persentase sebanyak 43,1949 dari total 13 indikator yang seharusnya diungkapkan. Standar deviasi variabel dimensi ekonomi dari jumlah observasi sebesar 23,49716 yang berarti penyebaran dan variasi data semakin kecil $(23,49716<43,1949)$. Untuk nilai maksimum variabel dimensi ekonomi memiliki nilai 100,00 yang berarti bahwa terdapat perusahaan sampel telah mengungkapkan dimensi ekonomi dalam Sustainability Report sesuai indeks GRI Standard sebesar 13 Indikator yang diungkapkan dari total 13 indikator yang diharapkan diungkapkan. Sedangkan nilai minimum variabel dimensi ekonomi memiliki nilai minimum sebesar 0,00 . Hal ini berarti terdapat perusahaan sampel yang tidak melakukan pengungkapan dimensi ekonomi dari total 13 indikator yang seharusnya diungkapkan dalam Sustainability Report sesuai indeks GRI Standard.

Rata-rata variabel dimensi lingkungan yang diukur dengan GRI Standard adalah 30,0853. Hal ini dapat diartikan bahwa rata-rata perusahaan yang dijadikan sampel mengungkapkan dimensi lingkungan dalam Sustainability Report sesuai indeks GRI Standard sebesar 30,0853 persen yang diungkapkan dari total 30 indikator yang seharusnya diungkapkan. Standar deviasi variabel dimensi lingkungan dari jumlah observasi sebesar 21,36110 . Hal ini berarti penyebaran dan variasi data semakin kecil $(21,36110<30,0853)$. 
Untuk nilai maksimum variabel dimensi lingkungan memiliki nilai maksimum sebesar 100,00. Hal ini dapat diartikan bahwa nilai maksimum perusahaan yang dijadikan sampel mengungkapkan dimensi lingkungan dalam Sustainability Report sesuai indeks GRI Standar sebesar 30 Indikator yang diungkapkan dari total 30 indikator yang seharusnya diungkapkan. Sedangkan dimensi lingkungan memiliki nilai minimum sebesar 0,00 yang berarti terdapat perusahaan sampel yang tidak mengungkapkan dimensi lingkungan dari total 30 indikator yang seharusnya diungkapkan dalam Sustainability Report sesuai indeks GRI Standard.

Rata-rata nilai dimensi sosial yang diukur dengan GRI Standar adalah 35,3319. Hal ini dapat diartikan bahwa rata-rata perusahaan yang dijadikan sampel mengungkapkan dimensi sosial dalam Sustainability Report sesuai indeks GRI Standar sebesar 35,33 persen dari dari total 34 indikator yang seharusnya diungkapkan. Standar deviasi variabel dimensi sosial dari jumlah observasi sebesar 19,93876 Hal ini berarti penyebaran dan variasi data semakin kecil $(19,93876<35,3319)$. Untuk nilai maksimum variabel dimensi sosial memiliki nilai maksimum sebesar 94,12 yang. Hal ini dapat diartikan bahwa nilai maksimum perusahaan yang dijadikan sampel mengungkapkan dimensi sosial dalam Sustainability Report sesuai indeks GRI Standard sebesar 32 indikator yang diungkapkan dari total 34 indikator yang seharusnya diungkapkan. Nilai minimum variabel dimensi sosial memiliki nilai sebesar 8,82 . Hal ini dapat diartikan bahwa perusahaan sampel mengungkapkan dimensi sosial dalam Sustainability Report sesuai indeks GRI Standard sebesar 3 Indikator yang diungkapkan dari total 34 indikator yang seharusnya diungkapkan.

Rata-rata (mean) variabel kinerja keuangan yang diukur dengan Return on Asset (ROA) sebesar 4,2235. Standar deviasi variabel Return on Asset (ROA) dari jumlah observasi sebesar 4,99211. Hal ini berarti penyebaran dan variasi data semakin luas (4,99211 > 4,2235). Untuk nilai maksimum Return on Asset (ROA) sebesar 20,68. Hal ini menggambarkan kemampuan perusahaan dalam mengelola asetnya untuk memperoleh laba yang tinggi sangat baik. Nilai minimum variabel Return on Asset (ROA) sebesar -9,58 yang mengindikasikan kurangnya kemampuan perusahaan mengelola assetnya secara efektif sehingga memperoleh laba negatif.

Rata-rata variabel kinerja pasar yang diproksikan dengan Tobin's Q sebesar 1,4714. Standar deviasi variabel kinerja pasar dari jumlah observasi sebesar 1,5784. Hal ini berarti penyebaran dan variasi data semakin luas $(1,5784>1,4714)$. Untuk nilai maksimum kinerja pasar sebesar 10,5. Hal ini menggambarkan bahwa saham perusahaan dinilai sangat tinggi dibandingkan nilai bukunya, sehingga nilai perusahaan sangat tinggi. Informasi tersebut menjadi sinyal positif bagi calon investor untuk menanamkan dananya pada perusahaan tersebut. Nilai minimum variabel kinerja pasar sebesar 0,26 yang berarti bahwa saham perusahaan dinilai sangat rendah dengan nilai bukunya, sehingga kinerja pasar sangat rendah karena kinerja pasar dibawah nilai 1 yang biasanya dianggap sebagai saham yang harganya murah. Informasi tersebut membuat para investor enggan untuk menginvestasikan dananya kepada perusahaan tersebut.

Sebelum melakukan pengujian regresi linier berganda, telah dilakukan uji asumsi klasik yang terdiri dari uji normalitas, heterokedastisitas, multikolinieritas dan autokorelasi. Hasil pengujian asumsi klasik menunjukkan bahwa semua variabel telah memenuhi persyaratan uji asumsi klasik sehingga dapat dilanjutkan dengan tahapan pengujian selanjutnya. Hasil pengujian regresi linier berganda disajikan pada tabel 2. Uji statistik F 
merupakan uji model yang menunjukkan apakah semua variabel independen atau bebas yang dimasukkan dalam model mempunyai pengaruh secara bersama-sama terhadap variabel dependen (Ghozali, 2005: 88). Hasil pengujian statistik F untuk model pertama menunjukkan bahwa nilai $\mathrm{F}$ hitung sebesar 3,959 dengan probabilitas 0,012. Oleh karena probabilitas jauh lebih kecil dari 0,05 maka model regresi dapat digunakan untuk memprediksi kinerja keuangan atau dapat dikatakan bahwa dimensi ekonomi, dimensi lingkungan, dan dimensi sosial secara bersama-sama berpengaruh terhadap kinerja keuangan yang diproksikan dengan Return on Asset (ROA). Hasil pengujian model kedua dengan menggunakan kinerja pasar sebagai variabel dependen menunjukkan nilai $\mathrm{F}$ hitung 0,884 dengan probabilitas 0,454 . Oleh karena probabilitas jauh lebih besar dari 0,05, maka model regresi tidak dapat digunakan untuk memprediksi kinerja pasar atau dapat dikatakan bahwa dimensi ekonomi, dimensi lingkungan, dan dimensi sosial secara bersama-sama tidak berpengaruh terhadap kinerja pasar yang diproksikan dengan Tobin's Q.

Koefisien determinasi $\left(\mathrm{R}^{2}\right)$ pada intinya mengukur seberapa jauh kemampuan model dalam menerangkan variasi variabel dependen (Ghozali, 2005: 83). Hasil pengujian koefisien determinasi $\left(\mathrm{R}^{2}\right)$ untuk model pertama menunjukkan bahwa nilai Adjusted $\mathrm{R}^{2}$ sebesar 0,114 atau 11\%. Nilai tersebut menandakan kemampuan variabel dimensi ekonomi, dimensi lingkungan, dan dimensi sosial dalam menjelaskan variabel kinerja keuangan yang diproksikan dengan Return on Asset (ROA) yaitu sebesar 11\%. Sedangkan sisanya 89\% variasi variabel kinerja keuangan dijelaskan oleh faktor lain yang tidak dimasukkan ke dalam model perhitungan. Sedangkan untuk pengujian model kedua menunjukkan bahwa nilai Adjusted $\mathrm{R}^{2}$ sebesar -0.005 atau $0 \%$. Nilai negatif tersebut menandakan kemampuan variabel dimensi ekonomi, dimensi lingkungan, dan dimensi sosial dalam menjelaskan variabel kinerja pasar yang diproksikan dengan Tobin's $Q$ yaitu sebesar $0 \%$.

Uji signifikansi parameter individual (uji statistik t) menunjukkan seberapa jauh pengaruh satu variabel penjelas atau independen secara individual dalam menerangkan variasi variabel dependen (Ghozali, 2005: 84). Hasil pengujian signifikan parameter individual (Uji statistik t) untuk model pertama menunjukkan bahwa nilai signifikansi dimensi ekonomi lebih kecil dari 0,05 atau 0,049<0,05 dengan arah koefisien positif sehingga hipotesis pertama $\left(\mathrm{H}_{1}\right)$ diterima. Hal ini berarti dimensi ekonomi dan kinerja keuangan yang diproksikan menggunakan ROA terdapat pengaruh yang signifikan positif. Nilai signifikansi dimensi lingkungan lebih kecil dari 0,05 atau 0,006 $<0,05$ dengan arah koefisien positif, yang berarti bahwa hipotesis kedua $\left(\mathrm{H}_{2}\right)$ diterima. Dengan demikian dimensi lingkungan dan kinerja keuangan yang diproksikan menggunakan ROA terdapat pengaruh yang signifikan positif. Nilai signifikansi dimensi sosial lebih kecil dari 0,05 atau $0,009<0,05$ dengan arah koefisien negatif sehingga hipotesis ketiga $\left(\mathrm{H}_{3}\right)$ ditolak. Dengan demikian dimensi sosial dan kinerja keuangan yang diproksikan menggunakan ROA terdapat pengaruh yang signifikan dengan arah hubungan negatif.

Hasil pengujian pada model kedua dengan menggunakan kinerja pasar (Tobin's Q) menunjukkan bahwa nilai signifikansi dimensi ekonomi lebih besar dari 0,05 atau 0,186> 0,05 dengan arah koefisien positif sehingga hipotesis keempat (H4) ditolak. Hal ini artinya dimensi ekonomi berpengaruh positif namun tidak signifikan terhadap kinerja pasar yang diproksikan menggunakan Tobin's Q. Nilai signifikansi dimensi lingkungan lebih besar dari 
0,05 atau $0,528>0,05$ dengan arah koefisien negatif sehingga hipotesis kelima (H5) ditolak. Dengan demikian dimensi lingkungan berpengaruh negatif tidak signifikan terhadap kinerja pasar yang diproksikan menggunakan Tobin's Q sebagai variabel dependen. Hasil pengujian pengaruh dimensi sosial terhadap kinerja pasar menunjukkan nilai signifikansi dimensi sosial lebih besar dari 0,05 atau 0,556 $>0,05$ dengan arah hubungan negatif sehingga hipotesis keenam (H6) ditolak. Dengan demikian artinya dimensi sosial dan kinerja pasar yang diproksikan menggunakan Tobin's $Q$ tidak terdapat pengaruh yang signifikan.

Tabel 2 Ringkasan Hasil Pengujian Hipotesis

Uji Statistik F Koefisien Determinasi $\left(\mathrm{R}^{2}\right) \quad$ Uji Statistik $\mathrm{t}$

\begin{tabular}{|c|c|c|c|c|c|c|c|c|}
\hline \multirow[b]{2}{*}{ Model Regresi } & \multirow[b]{2}{*}{ Variabel } & & & & & & & \\
\hline & & $\mathrm{F}$ & Sig. & $\begin{array}{c}\mathrm{R} \\
\text { Square }\end{array}$ & $\begin{array}{l}\text { Adjusted } \\
\text { R Square }\end{array}$ & Koefisien & $\mathrm{T}$ & Sig. \\
\hline \multirow{4}{*}{$\begin{array}{c}\text { Model } 1 \\
(\mathrm{Y}=\mathrm{ROA})\end{array}$} & (Constant) & \multirow{4}{*}{3.959} & \multirow{4}{*}{$.012^{\mathrm{a}}$} & \multirow{4}{*}{.152} & \multirow{4}{*}{.114} & 2.866 & 4.306 & .000 \\
\hline & Ekonomi & & & & & .248 & 2.007 & $.049 *$ \\
\hline & Lingkungan & & & & & .371 & 2.852 & $.006^{*}$ \\
\hline & Sosial & & & & & -.379 & -2.699 & $.009^{*}$ \\
\hline \multirow{4}{*}{$\begin{array}{c}\text { Model } 2 \\
(\mathrm{Y}=\text { Tobin's Q) }\end{array}$} & (Constant) & \multirow{4}{*}{.884} & \multirow{4}{*}{$.454^{\mathrm{a}}$} & \multirow{4}{*}{.035} & \multirow{4}{*}{-.005} & .136 & .691 & .492 \\
\hline & Ekonomi & & & & & .167 & 1.334 & .186 \\
\hline & Lingkungan & & & & & -.084 & -.634 & .528 \\
\hline & Sosial & & & & & -.085 & -.592 & .556 \\
\hline
\end{tabular}

Hasil analisis data menunjukkan bahwa pengungkapan dimensi ekonomi berpengaruh positif signifikan terhadap kinerja keuangan yang diproksikan dengan Return on Asset (ROA), hal ini dibuktikan dengan nilai standardized beta coefficients sebesar 0,248 dengan probabilitas signifikan sebesar 0,049. Nilai signifikansi dimensi ekonomi lebih kecil dari 0,05 . Berpengaruh positif artinya bahwa semakin luas pengungkapan dimensi ekonomi yang dilakukan oleh perusahaan maka akan meningkatkan kinerja keuangan yang diproksikan dengan Return on Asset (ROA). Hal ini menunjukkan bahwa semakin tinggi pengungkapan sustainability report dalam dimensi ekonomi yang dilakukan perusahaan maka semakin tinggi pula Return on Asset (ROA) yang diterima perusahaan. Pengungkapan Sustainability Report dalam dimensi ekonomi dapat menciptakan citra dan image yang baik bagi perusahaan, baik di pasar komoditas maupun pasar modal. Citra perusahaan yang baik akan lebih diminati oleh investor karena semakin baik citra perusahaan, maka semakin tinggi loyalitas konsumen maka penjualan perusahaan akan meningkat, sehingga kinerja keuangan perusahaan akan meningkat. Hasil penelitian ini sejalan dengan penelitian yang dilakukan oleh Simbolon dan Memed (2016), Bukhori dan Dani (2017), dan Putri (2017) yang menyatakan bahwa pengungkapan dimensi ekonomi berpengaruh terhadap kinerja keuangan yang diproksikan dengan Return on Asset (ROA).

Hasil analisis terhadap pengungkapan dimensi ekonomi menunjukkan pengaruh positif tidak signifikan terhadap kinerja pasar yang diproksikan dengan Tobin's Q, hal ini dibuktikan dengan nilai standardized beta coefficients sebesar 0,167 dengan probabilitas signifikan sebesar 0,186. Nilai signifikansi 0,186 lebih besar dari 0,05 dengan arah koefisien regresi positif. Berpengaruh positif artinya bahwa semakin luas pengungkapan dimensi ekonomi yang dilakukan oleh perusahaan maka akan meningkatkan kinerja pasar yang 
diproksikan dengan Tobin's Q. Hal ini dikarenakan informasi yang dihasilkan oleh sustainability report dalam dimensi ekonomi dengan menguji kinerja pasar perusahaan akan memengaruhi investor dalam membuat keputusan berinvestasi. Namun demikian dalam penelitian ini menemukan bahwa pengungkapan dimensi ekonomi tidak signifikan direspon oleh investor yang ditunjukkan dengan nilai signifikansi diatas 0,05 . Hal ini disebabkan oleh kurangnya pemahaman (perhatian) investor dipasar modal Indonesia akan manfaat sustainability report yang bersifat jangka panjang (Budiman dan Supatmi, 2009). Hasil penelitian ini sejalan dengan penelitian Sejati dan Andri (2015) yang menyatakan bahwa pengungkapan dimensi ekonomi tidak berpengaruh terhadap kinerja pasar yang diproksikan dengan Tobin's Q.

Hasil pengujian juga menyatakan bahwa pengungkapan dimensi lingkungan berpengaruh positif signifikan terhadap kinerja keuangan yang diproksikan dengan Return on Asset (ROA), hal ini dibuktikan dengan nilai standardized beta coefficients sebesar 0,371 dengan probabilitas signifikan sebesar 0,006 yang lebih kecil dari 0,05. Hal ini menunjukkan pengaruh signifikan pengungkapan dimensi lingkungan terhadap kinerja keuangan. Berpengaruh positif artinya bahwa semakin luas pengungkapan dimensi lingkungan yang dilakukan oleh perusahaan maka akan meningkatkan kinerja keuangan yang diproksikan dengan Return on Asset (ROA). Hal ini menunjukkan bahwa dengan adanya pengungkapan sustainability report dalam dimensi lingkungan sebagai salah satu bentuk transparansi perusahaan kepada investor dapat meningkatkan citra perusahaan dimata investor sehingga akan menarik minat untuk berinvestasi pada perusahaan tersebut. Hasil penelitian ini sejalan dengan penelitian yang dilakukan oleh Wijayanti (2016) yang menyatakan bahwa pengungkapan dimensi lingkungan berpengaruh terhadap kinerja keuangan yang diproksikan dengan ROA. Hal ini menunjukkan bahwa stakeholder merasa perlu adanya informasi mengenai dimensi lingkungan sehingga kebijakan yang diambil oleh stakeholder dapat menguntungkan perusahaan.

Hasil pengujian lainnya menunjukkan bahwa pengungkapan dimensi lingkungan berpengaruh negatif tidak signifikan terhadap kinerja pasar yang diproksikan dengan Tobin's Q, hal ini dibuktikan dengan nilai standardized beta coefficients sebesar $-0,84$ dengan probabilitas signifikan sebesar 0,528. Nilai signifikansi 0,528 lebih besar dari 0,05. Berpengaruh negatif artinya bahwa pengungkapan dimensi lingkungan dengan kinerja pasar memiliki arah yang berbeda dengan kata lain bahwa perusahaan yang mengungkapkan dimensi lingkungan belum tentu dapat meningkatkan kinerja pasar yang diproksikan dengan Tobin's Q. Hal ini menunjukkan bahwa tanggungjawab yang terkait dengan lingkungan masih dianggap sebagai biaya tambahan yang akan menurunkan peluang untuk memperoleh laba yang maksimal. Hasil penelitian ini sejalan dengan penelitian yang dilakukan oleh Sejati dan Andri (2015), Maskat (2018), dan Putri (2017) yang menyatakan bahwa pengungkapan dimensi lingkungan tidak berpengaruh signifikan terhadap kinerja pasar yang diproksikan dengan Tobin's Q. Hal ini disebabkan karena stakeholder lebih memilih perusahaan yang melakukan tindakan secara nyata tanpa harus menerbitkan pertanggungjawaban lingkungannya kepada masyarakat (Sejati dan Andri, 2015).

Hasil pengujian terhadap pengaruh pengungkapan dimensi sosial berpengaruh negatif signifikan terhadap kinerja keuangan yang diproksikan dengan Return on Asset (ROA), hal ini dibuktikan dengan nilai standardized beta coefficients sebesar -0,379 dengan probabilitas 
signifikan sebesar 0,009. Nilai signifikansi dimensi sosial lebih kecil dari 0,05 sehingga pengungkapan dimensi sosial berpengaruh terhadap kinerja keuangan. Berpengaruh negatif artinya ada hubungan tidak searah antara dimensi sosial dan kinerja keuangan yang diproksikan dengan Return on Asset (ROA). Hal ini menjelaskan bahwa semakin tinggi pengungkapan sustainability report dalam dimensi sosial akan berdampak terhadap penurunan kinerja keuangan perusahaan, hal ini diakibatkan karena pengungkapan sustainability report dalam dimensi sosial akan meningkatkan pengeluaran yang dilakukan oleh perusahaan sehingga akan berdampak pada penurunan laba perusahaan. Hasil penelitian ini sejalan dengan penelitian yang dilakukan oleh Sejati dan Andri (2015), Simbolon dan Memed (2016), dan Putri (2017) yang menyatakan bahwa pengungkapan dimensi sosial tidak berpengaruh terhadap kinerja keuangan yang diproksikan dengan Return on Asset (ROA).

Hasil pengujian terhadap pengungkapan dimensi sosial berpengaruh negatif tidak signifikan terhadap kinerja pasar yang diproksikan dengan Tobin's Q, hal ini dibuktikan dengan nilai standardized beta coefficients sebesar -0,85 dengan probabilitas signifikan sebesar 0,556. Nilai signifikansi 0,556 lebih besar dari 0,05. Berpengaruh negatif artinya bahwa pengungkapan dimensi sosial dengan kinerja pasar memiliki arah yang berlawanan dengan kata lain bahwa perusahaan yang mengungkapkan dimensi sosial belum tentu dapat meningkatkan kinerja pasar yang diproksikan dengan Tobin's Q. Hal ini menunjukkan bahwa pengungkapan sustainability report dalam dimensi sosial yang dilakukan perusahaan tidak mempengaruhi kinerja pasar secara signifkan. Anggapan mengenai perusahaan yang melakukan pengungkapan dimensi social hanya menjadi sebuah informasi bagi stakeholder yang tidak memberikan pengaruh terhadap kinerja pasar perusahaan itu sendiri (Sejati dan Andri, 2015). Hasil penelitian ini sejalan dengan penelitian yang dilakukan oleh Sejati dan Andri (2015), Maskat (2018), dan Putri (2017) yang menyatakan bahwa pengungkapan dimensi sosial tidak berpengaruh terhadap kinerja pasar yang diproksikan dengan Tobin's Q.

\section{Kesimpulan}

Hasil penelitian ini menunjukkan bahwa pengungkapan sustainability report dalam dimensi ekonomi dan dimensi lingkungan berpengaruh signifikan positif terhadap kinerja keuangan yang diproksikan dengan Return on Asset (ROA). Namun demikian, pengungkapan sustainability report dalam dimensi sosial berpengaruh signifikan negatif terhadap kinerja keuangan yang diproksikan dengan Return On Asset (ROA) mengindikasikan bahwa peningkatan pengungkapan dimensi sosial dalam pengungkapan sustainability report berdampak terhadap penurunan kinerja keuangan perusahaan yang diprediksi karena pengungkapan sustainability report dalam dimensi sosial akan meningkatkan pengeluaran yang dilakukan oleh perusahaan sehingga akan berdampak pada penurunan laba perusahaan. Hasil pengujian sustainability report dalam dimensi ekonomi, dimensi lingkungan, dan dimensi sosial tidak berpengaruh signifikan terhadap kinerja pasar yang diproksikan dengan Tobin's Q. Temuan ini menunjukkan pengungkapan sustainability report dalam dimensi ekonomi, lingkungan, dan sosial hanya dianggap informasi tambahan yang kurang dipertimbangkan dalam pengambilan kebijakan investasi oleh investor.

Hasil penelitian ini memberikan implikasi bahwa isu keberlanjutan telah 
dipertimbangkan sebagai bagian penting dalam pengambilan keputusan bisnis perusahaan untuk meningkatkan kinerja keuangan, yang selain aspek ekonomi juga mempertimbangkan aspek sosial dan lingkungan. Hasil penelitian ini diharapkan dapat memberikan informasi yang bermanfaat bagi manajemen perusahaan untuk lebih mempertimbangkan informasi sosial dan lingkungan kinerja ekonomi dalam pengambilan keputusan bisnis. Bagi investor, ke depan isu-isu keberlanjutan perlu mendapat perhatian untuk dipertimbangkan dalam kebijakan investasi karena berkaitan dengan kinerja keberlanjutan perusahaan dalam jangka panjang. Penelitian ini memiliki keterbatasan karena menggunakan periode observasi yang relatif pendek selama tiga tahun yaitu tahun 2015-2017. Jumlah obervasi perusahaan juga relatif sedikit karena masih terbatas jumlah perusahaan yang melaporkan informasi keberlanjutan melalui sustainability report. Dengan demikian penelitian mendatang dapat memperpanjang periode pengamatan serta menggunakan sumber data berasal dari media pengungkapan keberlanjutan perusahaan lainnya seperti laporan tanggungjawab sosial perusahaan maupun media pelaporan keberlanjutan lainnya seperti internet reporting.

\section{Referensi}

Budiman, Ferry, dan Supatmi. 2009. Pengaruh Pengumuman Indonesia Sustainability Reporting Award (ISRA) terhadap Abnormal Return dan Volume Perdagangan Saham: Studi Kasus Pada Perusahaan Pemenang ISRA Periode 2005-2008. Jurnal Universiats Kristen Satya Wacana

Caesaria, Aisyah Farisa. B. Basuki. 2017. The study of sustainability report disclosure aspects and their impact on the companies' performance. The $17^{\text {th }}$ Annual Conference of the Asian Academic Accounting Association (2016 FourA Conference

Elkington, J. 1997. Cannibals with Forks: The Triple Bottom Line of 21st Century Business. Capstone.Oxford.

Freeman, R., 1983. Strategic Management a Stakeholder Approach. Prentice-Hall, New Jersey.

Ghozali, Imam. Anis Chariri. 2014. Teori Akuntansi. Semarang: Badan Penerbit Universitas Diponegoro.

Ghozali, imam. 2005. Aplikasi Analisis Multivaret dengan Program SPSS. Semarang: Badan Penerbit Universitas Diponegoro.

Horne, James, C.V. John. M. Wachowiz, Jr. 2012. Prinsip-Prinsip Manajemen Keuangan.Jakarta: Salemba Empat.

Karyawati, Ni Nyoman Ayu. Gede Adi Yuniarta. Edy Sujana. 2017. Pengaruh Tingkat Pengungkapan Laporan Keberlanjutan terhadap Kinerja Keuangan Perusahaan (Studi Empiris pada Perusahaan Non-Keuangan yang Terdaftar di Bursa Efek Indonesia Periode 2013-2015). Jurnal Akuntansi Universitas Pendidikan Ganesha, $7(1), 1-10$

Manisa, Dea Eka. Defung. 2017. Pengaruh Pengungkapan Sustainability Report terhadap Kinerja Keuangan Perusahaan Infrastruktur yang Terdaftar di Bursa Efek Indonesia. Jurnal. Fakultas Ekonomi dan Bisnis Universitas Mulawarman, 19(2), 174-187

Maskat, Andansari. 2018. Pengaruh Sustainability Report Terhadap Kinerja dan Nilai Perusahaan (Studi Empiris pada Perusahaan Sektor Pertambangan (mining) yang Terdaftar di Bursa Efek Indonesia tahun 2011-2016). Skripsi. Universitas Islam Indonesia Yogyakarta. 
Natalia, Maria. Yuliana Gunawan. Verani Carolina. 2016. Pengaruh Pengungkapan Tanggungjawab Sosial Perusahaan terhadap Kinerja Pasar dengan Moderasi Efektifitas Dewan Komisaris dan Independensi Dewan Komisaris. Jurnal Akuntansi, 8 (1), 45-64.

Pratiwi, R.N. \& A. Chariri. 2015. Akuntansi sebagai realitas ekonomi dan keagamaan: Mengungkap Nilai-nilai religius melalui foto dalam laporan tahunan. Diponegoro Journal of Accounting, 4 (3), 1-15.

Putri, Indika Meutia. 2017. Pengaruh Sustainability Report terhadap Kinerja Keuangan dan Pasar (Studi Empiris pada Perusahaan Non Keuangan yang Terdaftar di BEI Tahun 2014-2015). Skripsi. Fakultas Ekonomi dan Bisnis Universitas Lampung.

Sejati, Bima Putranto. Andri Prastiwi. 2014. Pengaruh Pengungkapan Sustainability Report Terhadap Kinerja dan Nilai Perusahaan. Jurnal Akuntansi. Fakultas Ekonomi dan Bisnis Universitas Diponegoro. 4(1), 1-12.

Simbolon, Junita. Memed Sueb. 2016. Pengaruh Pengungkapan Sustainability Report Terhadap Kinerja Keuangan Perusahaan (Studi Empiris pada Perusahaan Tambang dan Infrastruktur Subsektor Energi yang Terdaftar di BEI Tahun 20102014). Simposium Nasional Akuntansi XIX, Lampung.

Soelistyoningrum, Jenia Nur. 2011. Pengaruh Pengungkapan Sustainability Report Terhadap Kinerja Keuangan (Studi Empiris pada Perusahaan yang Terdaftar dalam Bursa Efek Indonesia). Skripsi. Fakultas Ekonomi Universitas Diponegoro.

Sugiyono. 2018. Metode Penelitian Kuantitatif, Kualitatif, dan R\&D. Bandung: Alfabeta. 2017. Statistik Untuk Penelitian. Bandung: Alfabeta.

Tarigan, Josusa \& Hatane Samuel. 2014. Pengungkapan Sustainability Report dan Kinerja Keuangan. Jurnal Akuntansi dan Keuangan. 16 (2), 88-101

Wijayanti, Rita. 2016. Pengaruh Pengungkapan Sustainability Report Terhadap Kinerja Keuangan Perusahaan. Seminar Nasional dan the 3rd Call for Syariah Paper.

Weber, O., Koellner, T., Habegger, D., Steffensen, H., \& Ohnemus, P. 2008. The Relation Between Sustainability Performance and Financial. Progress in Industrial Ecology - An International Journal, 5 (3), 236-254 